tropic effects on various other characters the distribution of these genes will be at random relative to their action on bristle number.

Genetisch Laboratorium der Rijksuniversiteit,

W. Soharloo

Loyden, The Netherlands.

1 Gibson, J. B., and Thoday, J. M., Iteredity, 17, 1 (1962).

${ }^{2}$ Mather, K., J. Genet., 43, 309 (1941).

'Mather, K., Biol. Rev., 18, 32 (1943).

'Mather, K., Biometrical Genetics (Methuen, 1940).

- Mather, K., Symp. Soc. Exp. Biol., 7, 86 (1953).

- Recve, E. C. R., and Robertson, F. W., J. Genet., 51, 276 (1953).

'Clayton, G. A., Morris, J. A., and Robertson, A., J. Genet., 55, 131 (1957).

${ }^{8}$ Waddington, C. H., The Strategy of the Genes (Allen and Unwin, 1957).

- Scharloo, W., Arch. Neerl. Zool., 14, 433 (1962).

so Mather, K., and Harrison, B. J., Heredity, 3, 1 (1949).

\section{Transmission and Segregation of a Non- chromosomal Factor controlling Streptomycin Resistance in Diploid Chlamydomonas}

Chromosomal and non-chromosomal mutations to streptomycin resistance have been described in Chlamydomonas reinhardi-3. The chromosomal mutants, $s r-1$, aro resistant to low levels of streptomyoin $(50-100 \mu \mathrm{g} / \mathrm{ml}$.), possess a Mendelian pattern of inheritance, are closely linked or allelic, and lio in the left arm of linkago group IX. The non-chromosomal mutants, $s r-2$, aro resistant to high levels of streptomycin $(500 \mu \mathrm{g} / \mathrm{ml}$.) and exhibit a uniparental pattorn of inheritance. When a mating is made botween wild-type cells $(s s)$ and cells of an $s r-2$ mutant, all the progeny in each tetrad are, with rare exceptions ${ }^{1,4}$, endowed with the resistance-level of the mating type plus $\left(m t^{+}\right)$parent. The purpose of the present communication is to show that this pattern breaks down when diploids are made between $s r-2$ and $s s$ cells and that a large proportion of the diploid clones sogregate both resistant and sensitive colls during vegetative growth.

The method for obtaining diploid cells in $O$. reinhardi was recontly devised by Ebersold ${ }^{5}$, and only a brief description of the procodure will be presented here since it will be described in detail elsewhere ${ }^{5,6}$. In the present experiments, reciprocal matings wero mado between two non-allelic arginine-requiring mutants according to the method of Eborsold and Levine ${ }^{7}$. The two mutants, arg-1 and arg-2, complement in diploids ${ }^{5,6}$ and are located six map units apart in linkage group I (ref. 7). The arg-2 parent always carried tho $s r-2$ mutation while the arg-1 parent was always $s s$. In each experiment the cells were mated for $1 \mathrm{~h}$ and then the mating mixture was plated directly on minimal medium supplemented with sodium acetate ${ }^{3}$. The plates were incubated in the light at $27^{\circ} \mathrm{C}$ for soveral days after which visible colonies had appeared on them.

Since the original mating mixture had contained normal zygotes as well as diploid cells, tho colonies included prototrophic haploid recombinants produced by germinated zygotes in addition to diploid cells. Usually, the diploid colonies were larger than the colonies formed by the wild. typo rocombinants and they could be selected on this basis for further tosting. The most likely explanation of this phenomenon seems to be that the diploids begin to divido soon after being plated while the zygotes giving rise to wild-type recombinants probably do not begin to germinato for at least $36 \mathrm{~h}$. After a number of presumed diploid colonies had been isolated, they were tested for mating type and streptomycin resistance. The $m t$ gene lies in linkago group VI (ref. 8) and assorts independently of the arg mutants so that one half of the wild-type recom. binants are $m t^{+}$and the other half are $m t^{-}$. Diploids, on the other hand, are always $m t$ - in phenotype probably because $m t^{-}$is dominant to $m t^{+}$(rofs. 5 and 6). Therefore, the mating type test could be used to estimato tho proportion of diploids and wild-typo rocombinants isolated in a given experiment. Fortunately, all colonies tested proved to be $m t^{-}$in tho exporiments to be discussed. In a number
Table 1. Transmisston aND SEgREgamion of StrmptomyciN RESTSTaNCF $\triangle N D$ SENSTTIVITY IN DIPLOIDS DERIVED KROM RECIPROCAL CROSSES BETWEEN

Cross

Percentage

reentage of $88 \mathrm{cell}$ in diploid clone

100 8T-2 AND 88 CELLS

$80-60$

$60-40$

40-20

20-0

0

$s r-2 m t^{+} \times s 8 m t^{-}$

${ }_{1}^{\text {ss } m t^{+}} \times_{2} s r-2 m t^{-}$

$\begin{array}{cc}5 \cdot 55 & \\ (3 / 54) & (1 / 8 \\ 0 \cdot 00 & 1 \\ (0 / 37) & (1 / 5 \\ 5 \cdot 10 & 3 \\ (2 / 37) & (2 / 5 \\ 7 \cdot 65 & 1 \\ (3 / 37) & (7 \\ 15 \cdot 30 & \\ (6 / 37) & (4 \\ 20 \cdot 40 & 2 \\ (8 / 37) & (12 / 5 \\ 45 \cdot 80 & 5 \\ (18 / 37) & (27 / 5\end{array}$

$1 \cdot 24$
$(1 / 82)$
1.86
$(1 / 53)$
3.72
$(2 / 53)$
13.00
$(7 / 53)$
7.45
$(4 / 53)$
$22 \cdot 30$
$12 / 53)$
$50 \cdot 40$
$27 / 53)$

$1 \cdot 85$

$\begin{array}{ccc}24 \cdot 50 & \mathbf{4 4} \cdot 50 & 6 \cdot 70 \\ (22 / 90) & (12 / 27) & (8 / 90)\end{array}$

$\begin{array}{cccc}0.00 & 0.00 & 15.10 & (6 / 90) \\ 4.91\end{array}$

$\begin{array}{cccc}(0 / 28) & (0 / 12) & (3 / 11) & (3 / 57) \\ 3.50 & 12.50 & 15.10 & 8.25\end{array}$

$\begin{array}{ll}12 \cdot 50 & 15 \cdot 10 \\ (2 / 12) & (3 / 11)\end{array}$

$\begin{array}{lll}12 \cdot 50 & 15 \cdot 10 & (5 / 57) \\ (2.30 & \end{array}$

$\begin{array}{llll}(2 / 28) & (2 / 12) & (3 / 11) & (10 / 57) \\ 10 \cdot 50 & 12 \cdot 50 & 10.00 & 34 \cdot 40\end{array}$

(3/28)

$(2 / 12)$

$31 \cdot 90$

$10 \cdot 00$

$0.00 \quad 26.20$

$\begin{array}{lll}(5 / 12) & (0 / 11) & (16 / 57)\end{array}$

$\begin{array}{llllll}(18 / 37) & (27 / 53) & (11 / 28) & (1 / 12) & (0 / 11) & (2 / 57)\end{array}$

Figures not in parentheses indicate the percentage diploids in a given cross belonging to each of the categories listed. Figures in parcntheses show the actual number of diploids in a given category and the total number of diploids examined. In all crosses the $8 r-2$ parent carried the arg- 2 marker and the $s s$ parent carred the arg-1 marker.

of cases presumptive diploids were tested further by crossing them to haploid wild-type $m t^{+}$cells and screening the resulting tetrads for arginine-requiring progeny. The two arginine-roquiring mutants can be distinguished by testing them on ornithine-containing medium since arg-1 will grow on either ornithine, citrulline, or arginine whereas $\operatorname{arg-2}$ will only utilizo arginine $\theta^{7}$ These crosses showod that all the presumptive diploids carried both the markers.

Two important points emerge in the oxperimontal results (Table 1). First, 50->90 per cent of the diploids arising from reciprocal crosses botween $s r-2$ and $s s$ cells produce mixed clones containing both resistant and sensitivo cells. This phenomenon cannot be oxplained by the assumption that the diploid nucleus is unstable since it has been found that three unlinked chromosomal markers do not segregate in a similar manner when the diploids are grown under non-solective conditions ${ }^{8}$. Secondly, although 50 por cent or more of the diploid clones are mixtures of $s r-2$ and ss cells, a certain amount of the polarity characteristic of an ordinary cross is retained. Thus, in a cross of $s r-2 m t^{-} \times s s m t^{+}$up to 50 per cent of the diploid clones may be composed ontirely of $s s$ cells while less than 10 per cent are composed only of $s \mathrm{r}-2$ cells. In the reciprocal cross the reverse is true.

If it is assumed that $s r-2$ and $s s$ represent alternate mutational states of the same factor, then in a normal cross the transmission of the factor present in the $m t^{-}$ parent is usually blocked while the transmission of the factor present in the $m t^{+}$parent is never blocked. Diploids probably arise because somo function necessary for normal zygote formation is never realized. Whatover this function may be, the function which results in the uniparental transmission of the $s r-2$ factor is also impaired or missing in most nowly formed diploid cells. As a result, the majority of diploid cells contain both $s s$ and $s r-2$ determinants and these determinants segregate during subsequent mitotic divisions.

This work was carried out in tho laboratory of Prof. Norman H. Giles, Yalo Univorsity, and was supported by a Public Hoalth Service training grant $(2 G-397-C 1)$. I thank Prof. Giles for providing the facilitios and necessary space.

Biological Laboratories,

Nicholas W. Gilliham*

Harvard University,

Cambridgo, Mass.

* Present address: Biological Iaboratories, Marvard University, Cambridge 38, Mass.

1 Sager, R., Proc. D.S. Nat. Acad. Sci., 40, 350 (1954)

'Sager, R., Science, 132, 1458 (1060).

${ }^{3}$ Gillham, N. W., and Tevine, R. P., Genetics, 47, 1463 (1962)

- Gillham, N. W., Genetits, 48, 431 (1963).

Ebersold, W. T. (in preparation).

Gillham, N. W. (in preparation)

'Ebersold, W. T., and Levine, R. P., Z. Vererbungslehre, 90, 74 (1959).

Ebersold, W. T., Levine, R. P., Levine, E. E., and Olmsted, M. A. Genetics, 47, 531 (1962). 